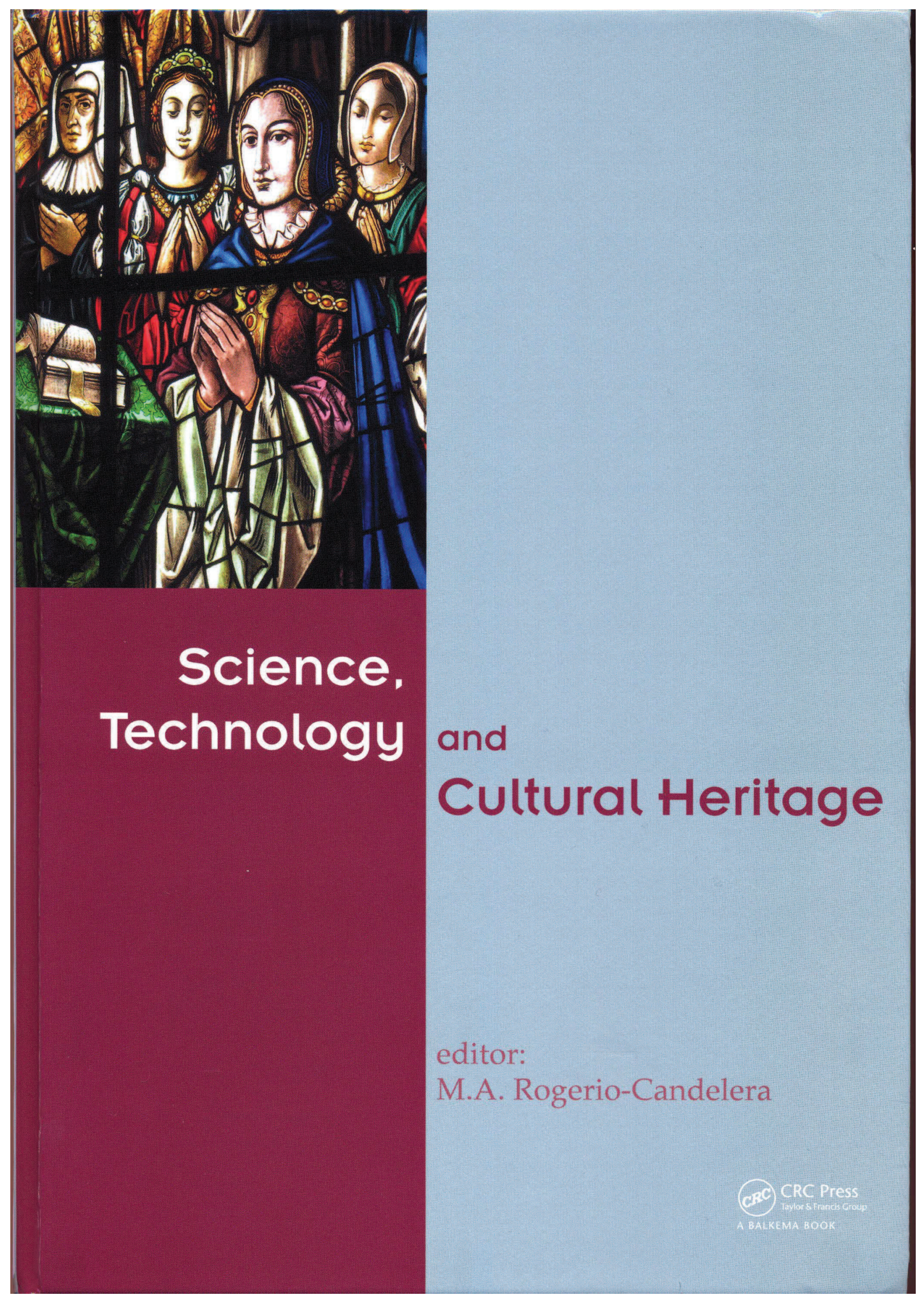


CRC Press/Balkema is an imprint of the Taylor \& Francis Group, an informa business

\section{(C) 2014 Taylor \& Francis Group, London, UK}

Typeset by V Publishing Solutions Pvt Ltd., Chennai, India Printed and bound in Great Britain by CPI Group (UK) Ltd, Croydon, CR0 4YY

All rights reserved. No part of this publication or the information contained herein may be reproduced, stored in a retrieval system, or transmitted in any form or by any means, electronic, mechanical, by photocopying, recording or otherwise, without written prior permission from the publisher.

Although all care is taken to ensure integrity and the quality of this publication and the information herein, no responsibility is assumed by the publishers nor the author for any damage to the property or persons as a result of operation or use of this publication and/or the information contained herein.

\section{Published by: CRC Press/Balkema}

P.O. Box 11320, 2301 EH Leiden, The Netherlands

e-mail: Pub.NL@taylorandfrancis.com

www.crcpress.com - www.taylorandfrancis.com

ISBN: 978-1-138-02744-2 (Hbk)

ISBN: 978-1-315-71242-0 (eBook PDF) 


\title{
Fluorescence in situ hybridisation for microbiological detection in mortars
}

\author{
R. Vieira \\ HERCULES Laboratory and Chemistry Department, Évora University, Évora, Portugal \\ P. Nunes, S. Martins \& M. González \\ HERCULES Laboratory, Évora University, Évora, Portugal \\ T. Rosado, A. Pereira, A. Candeias \& A.T. Caldeira \\ HERCULES Laboratory, Evora Chemistry Centre (CQE) and Chemistry Department, \\ Évora University, Évora, Portugal
}

\begin{abstract}
Microorganisms contribute significantly to monuments and artworks deterioration. Consequently, the improvement of our understanding of the microbial communities thriving on cultural heritage is crucial to the development of strategies for conserving it. New approaches are continuously being applied to assess cultural asset biodeterioration as well as to detect and identify the agents involved in it. In this work, the application of FISH technique for the detection of microbial community in mortars was explored. A universal eukaryotic probe (EUK516) labeled with a fluorescent dye (Cy3) was used, and different cell fixation conditions were tested, to investigate the application of FISH technique to detect eukaryotes in mortars. A series of selected fungi and yeast, most of them with known biodeteriogenic potential, were chosen as target microorganisms. The promising results obtained in this study, open up the possibility of investigate the application of FISH technique, not only for microbiological detection in mortars, but also as a tool to identify microorganisms directly in mortars by using specific probes. This simple and rapid approach could be useful on restoration and conservation fields.
\end{abstract}

\section{INTRODUCTION}

It is well established that microorganisms such as bacteria, fungi and algae play an important role in deterioration of cultural heritage. They can cause structural and aesthetic damage (Rosado et al. 2014). Microbiological research is crucial to identify the microbiological communities present in artworks for the development of correct conservation and restoration strategies (Sterflinger \& Piñar 2013). Although its relevance has been known for a long time, it has drawn more attention in the recent years. Modern molecular techniques in combination with classical cultivating methods, laborious, and time-consuming, have usually been used to provide a deeper understanding of the biodeteriogenic agents (Moter \& Göbel 2000). In situ techniques have been applied in order to gain insight into their spatial distribution (Sterflinger 2010) and new approaches are continuously being developed to detect and identify the microorganisms involved in biodeterioration of cultural assets, to better understand their role and to monitor their action.

The aim of this work is to apply the Fluorescence In Situ Hybridisation (FISH) technique to the detection of the microorganisms of interest in materials of cultural heritage. FISH is a simple, rapid and promising technique enabling the detection, visualisation and identification of the microorganisms (Bottari et al. 2006, Aoi 2002). This technique is based on the hybridisation of synthetic fluorochromes, which are labeled probes that bind to the target 